Original research / Orijinal araştırma

\title{
Association between serum leptin level and osteoporosis in patients with type 2 diabetes mellitus
}

Tip 2 diabetes mellitus hastalarında leptin düzeyi ile osteoporoz arasındaki ilişki

Tuncer Demir ${ }^{a 1}$, Sefa Gültürk ${ }^{b}$, Ercan Özdemir ${ }^{c}$, Şafak Şahin ${ }^{d}$, Bahattin Aydın ${ }^{d}$

a'Department of Physiology, Gaziantep University School of Medicine, Gaziantep

Departments of ${ }^{b}$ Physiology and ${ }^{d}$ Internal Medicine, Cumhuriyet University School of Medicine, Sivas

${ }^{\mathrm{C}}$ Department of of Internal Medicine, Sivas State Hospital, Sivas

\section{Abstract}

Aim: As osteoporosis and diabetes mellitus are widespread diseases, it is an important question whether leptin plays a role in bone physiology or not. In this study, we aimed to investigate the relationship between serum leptin level, diabetes and osteoporosis. Methods: The present study was conducted on 49 healthy individuals and 77 patients with type 2 Diabetes mellitus (DM), a total of 126 individuals, between 40 and 60 of ages. Between 08-10 hours in the morning, venous blood samples of $15 \mathrm{~mL}$ were drawn from forearm veins of the individuals and transferred into concerned test tubes. After blood samples were taken, Bioelectrical Impedance Analysis (BIA) was performed. Bone mineral density (BMD) was measured by DEXA (Dual energy $X$-ray absorptiometry) at $\mathrm{L}_{1-4}$ (anterior-posterior) and femur. Student $t$ test and correlation analysis were used for the statistical analysis in the study. Results: Leptin level of women in both groups were significantly higher than those of men in both groups $(p<0.05)$. BMD values of men in patient group was significantly lower compared to those of men in control group $(p<0.05)$. Similarly, BMD values of women in patient group was significantly lower compared to those of women in control group $(p<0.05)$. A positive correlation was found

\footnotetext{
${ }^{1}$ Corresponding author:

Dr. Tuncer Demir, Fizyoloji AD, Gaziantep Üniversitesi Tıp Fakültesi, TR-27310 Gaziantep

E-mail: drtuncer2003@yahoo.com
} 
between femur neck bone mineral density and leptin of men in both groups $(p<0.05)$. Conclusions: In terms of bone mineral density, femur neck measurements of women were more sensitive than $\mathrm{L}_{1-\mathrm{L} 4}$ measurements. Finding a positive correlation between femur neck bone mineral density and leptin levels in all men and having no such correlation in women may be related to more effective function of leptin hormone in men.

Keywords: Leptin, osteoporosis, type 2 diabetes mellitus

Özet

Amaç: Osteoporoz ve diyabet çok yaygın hastalıklar olduğu için, leptinin insan kemik fizyolojisinde herhangi bir rolü olup olmadığı önemli bir sorudur. Bu çalışmada, serum leptin konsantrasyonu ile diyabet ve osteoporoz arasındaki ilişkinin araştırıımasını amaçladık. Gereç ve Yöntem: Çalışma yaşları 40 ile 60 arasında değişen, tip 2 diabetes mellituslu (DM) 77 hasta ve 49 sağlıklı olmak üzere toplam 126 birey üzerinde yapılmıştır. Sabah saat 08:00-10:00 arası bireylerin ön kol venasından girilip yaklaşık 15 $\mathrm{mL}$ venöz kan örneği alınarak yapılacak testlerle ilgili deney tüplerine aktarıldı. Kan örnekleri alındıktan sonra tüm olgulara Biyoelektriksel İmpedans Analizi (BIA) uygulandı. Kemik mineral yoğunluğu (KMY) ise DEXA (Dual enerji X-ray absorptiometri) yöntemi ile $L_{1-4}$ (ön-arka) ve femurdan ölçüldü. Çalışmanın istatistiksel analizinde student $t$ testi ve korelasyon analizi kullanıldı. Bulgular: Kontrol ve hasta gruplarında kadınların leptin düzeylerinde görülen artış, erkeklerinkine göre anlamlı bulunmuştur $(p<0.05)$. Hasta erkek grubu kontrol grubu ile karşılaştırıldığında, KMY değeri anlamlı olarak düşük bulunmuştur $(p<0.05)$. Kadın hasta grubundaki KMY değerinde azalma kontrol gurubuna göre anlamlıydı $(p<0.05)$. Tüm erkeklerde femur boynu KMY değerleri ile leptin arasında pozitif bir korelasyon bulunmuştur $(p<0.05)$. Sonuç: Kadınlar KMY'ye göre değerlendirildiğinde femur boynu ölçümleri, $L_{1-L 4}$ ile karşılaştırıldığında daha hassasiyet göstermektedir. Tüm erkeklerde femur boynu KMY değerleri ile leptin arasında pozitif bir korelasyon bulunurken kadınlarda bulunmaması erkeklerde leptin hormonunun daha etkili olmasından kaynaklanabilir.

Anahtar sözcükler: Leptin, osteoporoz, tip 2 diabetes mellitus

\section{Introduction}

Leptin, which is a peptide hormone secreted primarily from fat cells and produced by fatty gene, increases energy consumption, regulates body weight (1) and insulin sensitivity (2) and limits food intake.

Osteoporosis is among the leading causes of mortality and morbidity that leads to a heavy economic burden at health institutions. Although it has not been proven yet by community-based screenings, determining risk groups and following them closely is a logical approach in preventing osteoporosis (3). Recent findings strongly support direct or indirect role of leptin. Effects of leptin are regulated by hypothalamo-pituitary pathway that also affects bone formation. Leptin receptors have been found in bone 
cells, and findings of in vitro studies have shown that leptin increases osteoblastic differentiation and inhibits osteclastic generation though local mechanisms $(4,5)$

Both osteoblasts and adipocytes use bone marrow stromal cells as pioneers. Clinical and experimental evidences indicate that bone cell functions are controlled by neuronal influences (6). Findings on effects of leptin on bone metabolism are partly contradictory. Cross-sectional studies on human subjects have shown various different results such as no relation between leptin and $\operatorname{BMD}(7,8)$ and a positive relation between leptin and bone mineral density (BMD) $(9,10)$. Other studies have revealed negative associations (11-13). Thomas et al. found that there is a sexual dimorphism in the said association, with a positive association in women but not in men (14). Reasons of these differences are not clear yet.

As osteoporosis and diabetes mellitus are widespread diseases, it is an important question whether leptin plays a role in bone physiology or not. In this study, we aimed to investigate the relationship between serum leptin level, diabetes and osteoporosis.

\section{Materials and methods}

The present study was conducted on 49 healthy individuals and 77 patients with type 2 DM presenting to Internal Diseases Department of Medical Faculty of Cumhuriyet University. It was paid attention that those in the control group and patients were of similar ages and those in control group had no known metabolic disease other than obesity at physical examination. Each group was further divided into two subgroups according to gender. Patients included in the study were screened for diabetic complications. All had normal albumin levels, their blood glucose levels were regulated and thyroid functions were normal.

A total of 126 individuals, between 40 and 60 of ages, were included to our present study. Demographic values of the individuals are given in Table 1. In order to avoid any effects on test results, both the patient and control group were advised not to perform heavy exercises, smoke and consume alcohol starting a day before tests and not to eat starting a night before the tests. Between 08:00-10:00 in the morning, venous blood samples of $15 \mathrm{~mL}$ were drawn from forearm veins of the individuals and transferred into concerned test tubes. After blood samples were taken, Bioelectrical Impedance Analysis (BIA) was performed for all the cases $(15,16)$.

Bone mineral density was measured by DEXA (Dual energy $\mathrm{X}$-ray absorptiometry) at $\mathrm{L}_{1-4}$ (anterior-posterior) and femur. X-ray bone densitometry (Hologic $4500 \mathrm{~W}$, Acclaim, USA) equipment was used for DEXA measurement. During DEXA measurements, BMD was measured by asking the patient to lie in supine position with hips and knees put into 90 degree flexion to eliminate lombar lordosis and vertebrae at anterior-posterior (AP) position. Osteophytes and sclerotic edges observed on the screen were left out of the measurement field.

Serum leptin level was measured by radio-immunoassay (RIA) method using human 
leptin IRMA kit (Diagnostic Systems Laboratories [DSL, USA] No:23100). Insulin measurements were performed on Immulite 2000 automatic analyzer equipment $(\mu \mathrm{IU} / \mathrm{mL})$ using enzyme immunoassay method at the Nucleer Medicine Department of our faculty. Insulin kit of Diagnostic Products Corporation (DPC) with a sensitivity of 2 $\mu \mathrm{IU} / \mathrm{mL}$ was used for this purpose.

Data were presented as mean \pm SD. Student $t$ test and correlation analysis were used for the statistical analysis in the study. A $p$ value of less than 0.05 was accepted as significant.

\section{Results}

In overall evaluation, there was no significant difference between the ages of women $(52.6 \pm 10.2)(n=25)$ and men $(53.8 \pm 9.3)(n=24)$ in control group and between the ages of women $(56.2 \pm 8.7)(n=47)$ and men $(58.2 \pm 10.5)(n=30)$ in diabetic group. Similarly, when compared in terms body weight, there was no significant difference between women $(74.56 \pm 15.06 \mathrm{~kg})$ and men in control group and between women $(72.30 \pm 15.72$ $\mathrm{kg}$ ) and men (70.23 \pm 15.90$)$ in diabetic group. When men and women were compared in terms of diabetic age, the different was not significant (women: $123.3 \pm 84.4$ ay; men : $102.5 \pm 65.1$ months). Both gender groups were not statistically different in terms of treatment duration (women: $55.5 \pm 53.6$; men: $47.1 \pm 58.0$ ) (Table 1).

Table 1. Demographic values and standard errors of all individuals.

\begin{tabular}{|l|l|l|l|l|}
\hline \multirow{2}{*}{} & \multicolumn{2}{|l|}{ Women } & Men \\
\cline { 2 - 5 } & Patients $(\mathrm{n}=47)$ & Controls $(\mathrm{n}=25)$ & Patients $(\mathrm{n}=30)$ & Controls $(\mathrm{n}=24)$ \\
\hline Age $(\mathrm{y})$ & $56.2 \pm 8.7$ & $52.6 \pm 10.2$ & $58.2 \pm 10.5$ & $53.8 \pm 9.3$ \\
\hline Body weight $(\mathrm{kg})$ & $72.30 \pm 15.7$ & $74.56 \pm 15.0$ & $70.23 \pm 15.9$ & $72.64 \pm 12.9$ \\
\hline Diabetes duration $(\mathrm{y})$ & $123.3 \pm 84.4$ & - & $102.5 \pm 65.1$ & - \\
\hline Treatment duration $(\mathrm{y})$ & $55.5 \pm 53.6$ & - & $47.1 \pm 58.0$ & - \\
\hline Insulin level & $14.78 \pm 16.19 \mathrm{~b}$ & $5.59 \pm 3.53$ & $10.75 \pm 11.87 \mathrm{a}$ & $5.39 \pm 4.46$ \\
\hline $\begin{array}{l}\text { ap<0.05 Compared with the control men } \\
\text { bp<0.05 Compared with the control women }\end{array}$ & & \\
\hline
\end{tabular}

Insulin values of the women in patient group were significantly higher compared to those of women in control group while insulin values of men in patient group were significantly higher compared to those of men in control group too $(p<0.05)$ (Table 1$)$.

Leptin level of women in both groups were significantly higher than those of men in both groups $(p<0.05)$. Both in women and men, there was no significant difference between patient and control group in terms of leptin level ( $p>0.05$ ) (Table 2).

When BMD of femur neck was evaluated, BMD values of men in patient group was significantly lower compared to those of men in control group $(p<0.05)$. Similarly, BMD values of women in patient group was significantly lower compared to those of women in control group $(p<0.05)$ (Table 2$)$.

When lumbar vertebrae bone mineral densities were compared, BMD values of women 
in control group were significantly lower than those of men in control group $(p<0.05)$; and BMD values of men in patient group were significantly lower than BMD values of both men in control group and women in patient group $(p<0.05)$ (Table 2 ).

Table 2. Average bone mineral density (BMD) and leptin values of all individuals.

\begin{tabular}{|c|c|c|c|c|}
\hline & \multicolumn{2}{|l|}{ Women } & \multicolumn{2}{|l|}{ Men } \\
\hline & Patients $(n=47)$ & Controls $(n=25)$ & Patients $(n=30)$ & Controls $(n=24)$ \\
\hline Leptin $(\mathrm{ng} / \mathrm{mL}$ ) & $37.6 \pm 24.0^{\mathrm{e}}$ & $29.7 \pm 12.3^{g}$ & $9.3 \pm 6.6$ & $8.7 \pm 5.9$ \\
\hline Femur neck $(\mathrm{gr} / \mathrm{cm} 2)$ & $0.8 \pm 0.1^{\mathrm{c}}$ & $0.9 \pm 0.1$ & $0.8 \pm 0.1^{\mathrm{a}}$ & $0.9 \pm 0.1$ \\
\hline L1-L4 (gr/cm2) & $0.9 \pm 0.1^{\mathrm{d}}$ & $0.9 \pm 0.1^{f}$ & $0.7 \pm 0.0^{b}$ & $1.0 \pm 0.1$ \\
\hline
\end{tabular}

A positive correlation was found between femur neck bone mineral density and leptin of men in both groups $(p<0.05)$ (Table 3$)$.

Table 3. Leptin values of all individuals and bivariate correlation of other parameters.

\begin{tabular}{|c|c|c|c|c|c|c|c|c|}
\hline \multirow[b]{3}{*}{ BMD } & \multicolumn{4}{|c|}{ Women } & \multicolumn{4}{|l|}{ Men } \\
\hline & \multicolumn{2}{|c|}{ Patients $(n=47)$} & \multicolumn{2}{|c|}{ Controls $(n=25)$} & \multicolumn{2}{|c|}{ Patients $(n=30)$} & \multicolumn{2}{|c|}{ Controls $(n=24)$} \\
\hline & $r$ & Significance & $r$ & Significance & $r$ & Significance & $r$ & Significance \\
\hline Femur neck & 0.1 & $>.05$ & 0.32 & $>.05$ & 0.53 & $<.05 b$ & 0.50 & $<.05 a$ \\
\hline L1-L4 & -0.1 & $>.05$ & 0.13 & $>.05$ & 0.26 & $>.05$ & 0.23 & $>.05$ \\
\hline
\end{tabular}

\section{Discussion}

As osteoporosis and diabetes mellitus are widespread diseases, it is an important question whether leptin plays role in the bone physiology or not. For this reason, determining the relation between blood level and obesity and BMD in patients having DM would provide clinically important information.

It is well established that obesity has a protective effect against osteoporosis. Various studies have revealed that obesity plays an important role in protecting BMD and bone quality $(17,18)$. As both bone density and leptin levels depend on body weight, it has been suggested that leptin may play a mediating role in maintaining bone mass in obese people (10).

Effect of leptin on bone metabolism has not been clear yet. It has been shown that leptin promotes bone formation by increasing human osteoblast proliferation, collagen synthesis and mineralization (19). Moreover, there exist studies arguing leptin inhibits osteoclast generation and bone resorption (20). In experimental studies, it has been shown that leptin inhibits new bone formation not through endocrine or paracrine action but through its effect on the central nervous system mediated by hypothalamus. 
Peripheral leptin administration has been shown to induce bone formation, increase osteoblast differentiation and inhibit adipocyte differentiation in ob/ob mice and thus has an effect on human marrow stromal cells $(4,21)$. Moreover, as it has been reported that serum leptin levels, independent of adipocyte, are higher in women than men $(11,22)$, a hypothesis that estrogen may have an effect on leptin secretion has been set forth.

Studies on the association of serum leptin level and bone mineral density in human are contradictory. There are studies where a positive association has been found between leptin and BMD $(14,23)$ while there are also studies reporting no significant association $(8,24)$ or a negative association $(13,25)$

Yamauchi et al. (26) claimed that there is a relation between low plasma leptin levels and vertebral fractures in postmenapousal women and thus circulating leptin might play a physiological role in improving bone mass quality. Unsurprisingly, insulin values of the patients were significantly higher than controls, independent of gender.

According to our findings, leptin values of diabetic patients and healthy individuals were not significantly different and values were higher in women than men, which suggest leptin is basically associated with fat tissue and gender. Although leptin values were different between genders both in patient and control group, there was no difference between leptin values of men in patient and control group or between leptin values of women in patient and control group. That is to say, the difference in terms of leptin was not related with type 2 diabetes but with gender.

When femur neck and lumbal vertebrae were compared in terms of bone mineral density, there was a difference in both between men in patient group and control group while the significant difference was not in vertebrae values but in femur neck values in women, which shows that femur neck is a valuable measurement in both genders

According to the results we have obtained, Type $2 \mathrm{DM}$ has an effect decreasing BMD in women and men. In terms of bone mineral density, femur neck measurements of women were more sensitive than $L_{1} L_{4}$ measurements. Finding a positive correlation between femur neck bone mineral density and leptin levels in all men and having no such correlation in women may be related to more effective function of leptin hormone in men.

\section{Conflicts of interest}

The authors did not declare any conflicts of interest.

\section{References}

1. Friedman $M$, and Halaas $\mathrm{JL}$. Leptin and the regulation of body weight in mammals. Nature 1998;395:763-70.

2. Arner P. Insulin resistance in type 2 diabetes - role of the adipokines. Curr Mol Med 2005;5:333-9. 
3. Hampson G, Evans C, Petitt RJ et al. Bone mineral density, collagen type $1 \propto 1$ genotypes and bone turnover in premenopausal women with diabetes mellitus. Diabetologia 1998;41:1314-20.

4. Thomas T, Gori F, Khosla S, Jensen MD, Burguera B and Riggs BL. Leptin acts on human marrow stromal cells to enhance differentiation to osteoblasts and to inhibit differentiation to adipocytes. Endocrinology 1999;140:1630-8.

5. Holloway WR, Collier FM, Aitken CJ, Myers DE, Hodge JM and Malakellis M et al. Leptin inhibits osteoclast generation. J Bone Miner Res 2002;17:200-9.

6. Ducy $P$, Amling M, Takeda S, Priemel M, Schilling AF and Beil FT et al. Leptin inhibits bone formation through a hypothalamic relay: a central control of bone mass. Cell 2000;100:197-207.

7. Odabasi E, Ozata M, Turan M, Bingol N, Yonem A, Cakir B, et al. Plasma leptin concentrations in postmenopausal women with osteoporosis. Eur J Endocrinol 2000;142:170-3.

8. Rauch F, Blum WF, Klein K, Allolio B and Schonau E. Does leptin have an effect on bone in adult women. Calcif Tissue Int 1998;63:453-5.

9. Pasco JA, Henry MJ, Kotowicz MA, Collier GR, Ball MJ and Ugoni AM et al. Serum leptin levels are associated with bone mass in nonobese women. J Clin Endocrinol Metab 2001,86:1884-7.

10. Roux C, Arabi A, Porcher R and Garnero P. Serum leptin as a determinant of bone resorption in healthy postmenopausal women. Bone 2003;33:847-52.

11. Ruhl CE and Everhart JE. Relationship of serum leptin concentration with bone mineral density in the United States population. J Bone Miner Res 2002;17:1896-903.

12. Sato $M$, Takeda N, Sarui $H$, Takami R, Takami $K$ and Hayashi $M$ et al. Association between serum leptin concentrations and bone mineral density, and biochemical markers of bone turnover in adult men. J Clin Endocrinol Metab 2001;86:5273-6.

13. Blum M, Harris SS, Must A, Naumova EN, Phillips SM and Rand WM. Leptin, body composition and bone mineral density in premenopausal women. Calcif Tissue Int 2003;73:27-32.

14. Thomas T, Burguera B, Melton LJ, Atkinson EJ, O'Fallon WM and Riggs BL et al. Role of serum leptin, insulin, and estrogen levels as potential mediators of the relationship between fat mass and bone mineral density in men versus women. Bone 2001;29:114-20.

15. Ellis KJ, Bell SJ, Chertow GM, Chumlea CW, Knox TA, Kotler PD, et al. Bioelectical impedance methods in clinical research: a follow-up to the NIH tecnology assesment confererence. Nutrition 1999;15:874-80.

16. Mcardle WD, Katch F, Katch VC. Exercise Physiology. Mcmillian Publishing Company First Edition, Baltimore 1996;151-63.

17. Haffner SM, Bauer LR. The association of obesity and glucose and insülin concentration with bone density in premenopausal and postmenopausal women. Metabolism 1993;42:735-8. 
18. Hyldstrup L, Andersen T, Mc Nair P. Bone metabolism in obesity: Changes related to severe overweight and dietary weight reduction. Acta Endocrinologica 1993;129:393-8.

19. Gordeladze JO, Drevon CA, Syversen U, Reseland JE. Leptin Stimulates Human Osteoblastic Cell Proliferation, De Novo Collagen Synthesis, and Mineralization: Impact on Differentiation Markers, Apoptosis, and Osteoclastic Signaling. J Cell Biochem 2002;85:825-36.

20. Holloway WR, Collier FM, Aitken CG, Malakellis M, Gough TJ, Myers DE, Collier GR, Nicholson GC. Leptin inhibits osteoclast generation. J Bone Miner Res 2000;15:S1;S174.

21. Steppan CM, Crawford DT, Chidsey-Frink KL, et al. is a potent stimulator of bone growth in ob/ob mice. Regul Pept 2000;92:73-8.

22. Castracane VD, Kraemer RR, Franken MA, Kraemer GR, Gimpel T. Serum leptin concentration in women: effects of age, obesity and estrogen administration. Fertil Steril 1998;70:472-7.

23. Goulding A, Taylor RW. Plasma leptin values in relation to bone mass and density to dynamic biochemical markers of bone resorption and formation in postmenopausal women. Calcif Tissue Int 1998;63:456-8.

24. Blain H, Vuillemin A, Guillemin F, Durant R, Hanesse B, Talance N et al. Serum leptin levels is a predictor of bone mineral density in postmenopausal women. J Clin Endocrinol Metab 2002;87:1030-5.

25. Westvik J. Radiological features in generalised lipodystrophy. Acta Paediatr 1996;413:44-51.

26. Yamauchi $M$, Sugimoto $T$, Yamaguchi $T$, et al. Plasma leptin concentrations are associated with bone mineral density and the presence of vertebral fractures in postmenopausal women. Clin Endocrinol (Oxf) 2001;55:341-7. 